\title{
ZIMBABWE : A Country Profile
}

\author{
Knocks Tapiwa Zengeni
}

\section{Introduction}

Zimbabwe is a relatively small country situated in the southern part of Africa between South - Africa and Zambia. It is also bounded by Mozambique in the east and Botswana in the West. This land-locked country occupies about $390,757 \mathrm{sq} \mathrm{km}$ of land and its population is about 12.4 million (CIA World Fact Book, 2011). Zimbabwe was a British colony for almost a century and was one of a few countries which belatedly achieved independence after waging a protracted liberation war. Several racial and ethnic groups reside in the county. English is the official language with two dominating native languages, that is, Shona - and SiNdebele being accorded national language status. Since 2000, Zimbabwe has been embroiled in the worst political and socio-economic crisis of its thirty-one year history as an independent state. Unfortunately, this unprecedented crisis has negatively affected every aspect of the country and every segment of the population. However, in February, 2009, after almost a year of uncertainty following controversial elections in 2008, a semblance of normality seems to have emerged after the main political actors agreed to set up an inclusive government. Despite these promising signs the country is still not out of the woods yet.

")

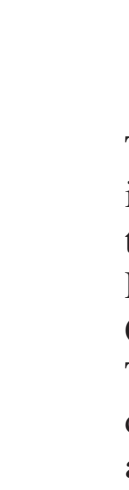

\section{History}

The current political and socio-economic crisis in Zimbabwe would not have been what it is today had it not been for colonial rule or history. When the British first came to what is today known as Zimbabwe they established contact with the Ndebele people under King Lobengula. Through those contacts, the British represented by the British South Africa Company (BSAC) later obtained mining concession in 1888 through the Rudd Concession. The catalyst for the BSAC machinations to take up Rhodesia was the discovery of gold during the 1880s in neighboring South Africa. When it soon became clear that Matabeleland and Mashonaland (Southern Rhodesia) was not a second El-Dorado, the BSAC had to pursue other opportunities to protect its investment, such as expropriation of native land and cattle. To realise these goals, a large settler class was needed and thus significant white migration into the country had begun in the 1890s under the direction of Cecil John Rhodes and his BSAC. Thus, the presence of a significant White settler population, or at least settler interests, emerges directly from the country's unique colonial history and as such represents a key feature in Zimbabwe's politics. More importantly it was the existence of this large settler community that was to distinguish Southern Rhodesia's political dynamics from other British colonies and protectorates. Native grievances fostered by colonial policies such as land alienation, cultural invasion and forced labour triggered the First Chimurenga 
or war of liberation in 1896/7, which was orchestrated by the two main indigenous tribes, namely, the Shona and the Ndebele. These African uprisings which nearly defeated the White settlers were only suppressed in 1897 after an additional British Expeditionary force was deployed to avert outright White defeat (Government of Zimbabwe, 2002, p.8).

The British later annexed Southern Rhodesia from the British South Africa Company in 1923, after the Colonial Office granted self-rule to Southern Rhodesia. At their peak in Rhodesia, there were never more than 270,000 Whites in the country and, at most, they accounted for 5.6 per cent of the total population (Central Statistical Office, 1985). In 1961 a constitution was formulated that favored whites in power. However, this constitution was rejected the African majority, whose leaders had initially accepted them. African nationalists who were inspired by fellow independent African countries like Ghana (1957) Nigeria (1960) and their former counterparts in the Federation of Rhodesia and Nyasaland (Zambia and Malawi), intensified their demands for immediate majority rule. White settlers became fearful that African rule endangered their lives and privileged status. In response, (1) Whe white settlers ditched the politics of moderation in Rhodesia in 1962 by electing the ultra-White nationalist party, the Rhodesia Front (RF) ahead of the moderate United Federal Party. The right- wing RF, won 35 of the 50 seats reserved for the white voters. In 1965 the RF, now under Ian Douglas Smith, received a more resounding victory by winning all 50 seats (Facchini, 2007, p.651). Not surprisingly, in the same year, the minority white government unilaterally declared its independence, but Britain did not recognize the act and demanded more complete voting rights for the black African majority in the country (then called Rhodesia after Northern Rhodesia gained independence in 1964 as Zambia). United Nations mandatory sanctions (which were violated by the United States after it passed the Amended Military Procurement Act of 1971) and a bloody war of liberation finally led to - free elections in 1979 and independence (as Zimbabwe) in 1980, after the conclusion of the Dancaster House Accords in Britain.



Zimbabwe's prospects appeared promising in 1980, as it gained independence after a long liberation war. ZANU PF emerged victorious in the elections after it won 57 of the contested 80 parliamentary seats, which gave it an overall majority. The Rhodesian Front of Ian Smith won all 20 seats that had been reserved for whites as per the provisions of Lancaster House Accords. Despite Mugabe's overwhelming victory, he had lost all the seats except one in Matabeleland to his uneasy liberation partner Joshua Nkomo's party showing that the his ascendancy to power was not broadly legitimized by the minority ethnic group. This glaringly ethnic flashpoint was a pointer to future conflicts along ethnic lines, which emerged in the early 1980s between Mugabe's Shona-dominated ZANU PF and Nkomo's Ndebele-based PF ZAPU. Another major challenge that confronted the new government was the demand by the black majority for greater equity in land distribution. At independence, the white minority, who composed less than $3 \%$ of the population, owned the vast majority of arable land, amounting to 15,5 million hectares and the majority black population who constituted more than 90 percent of the population occupied 16.4 million hectares of agricultural land, mainly in poor agro-zone regions. Many observers considered 
the country's white-owned commercial farms crucial to the country's economy, although there was a general recognition that land reform was necessary (Congressional Research Services, 2010, p.1). Britain initially funded a "willing buyer, willing seller" program to redistribute commercial farmland, offering compensation to white farmers amenable to leaving their lands. Effectively, at independence political power was ceded to the blacks and economic power remained wholly owned by local white and foreign capital. Ideologically, this new political dispensation was packaged as the policy of 'national reconciliation' by the new black-led government. To a great extent this post-independent dispensation in 1980 upheld the interests of the classes that dominated the social order and its characters in the process. For instance, historical imbalances were embedded in the Lancaster House Constitutional settlement that preserved the racially skewed pattern of land ownership. This was ironic considering that the "liberation war was fought over land and the promise to return it to the indigenous African population" (Tibaijuka Report, 2005, p.15). The disturbances that occurred in the country in the 1980s were effectively managed by the Unity Accord of 1987, which united ZANU PF and its former liberation ally, PF ZAPU. The Mugabe regime became fully consolidated, once the national unity pact was signed. The ZANU-ZAPU negotiated settlement and merger brought to an end the main organised black opposition to Mugabe's and ZANU-PF's rule. In a way this formalised Zimbabwe's move toward a de facto one-party state system which characterised the politics of the country for long periods before the emergence of the Movement for Democratic Change (MDC).

Rising inflation and unemployment bred discontent in the 1990s and led in 1999 to the formation of the opposition Movement for Democratic Change (MDC). At the same time, dissatisfaction with the pace of land reform grew in the rural areas and led in the 1990s to spontaneous and often violent farm invasions, led by traditional leaders and former liberation war fighters. The new opposition surprised many with its initial success, campaigning against a 2000 referendum that would have installed a new constitution that gave a blessing to radical land reform measures. The referendum failed, and the MDC won nearly half the seats in the 2000 parliamentary election. Members of President Robert Mugabe's ruling party subsequently took numerous, often undemocratic actions to maintain their grip on power. This culminated in the implementation of the controversial fast track land redistribution programme, which began in 2000. This programme triggered the expropriation of white-owned farms causing an exodus of white farmers. In the shortrun this crippled the economy, and ushered in widespread shortages of basic commodities. Notably, agricultural productivity declined rapidly and farm workers (the majority who originally came from neighbouring countries) lost their livelihoods and homes (AAPPG, 2009, p.38). Not with standing its difficult birth pangs and controversy the Fast Track Land Reform Programme (FTLRP) has not been entirely negative. It has broadened the access to land rights of the majority Black population, with more than 100, 000 families benefiting from the programme. This is supported by emerging research which shows that the impact of FTLRP on small holder commercial farms has been positives (Scoones 2008; Chaumba, Scoones \& Wolmer 2003; AAPPG, 2009, p.37). However, the implementation of radical land reforms targeting white-owned farms led Britain and other Western donors to withdraw financial support for land resettlement, and to impose sanctions against Zimbabwe. 
Since then, the country's problems have deepened. The country's economy declined rapidly between 2000 and 2008. Substantial political violence and human rights violations have accompanied elections since 2000. The pinnacle of such abuses in the wake of the 2008 March elections brought international condemnation, particularly from the West. Nonetheless, little consensus on how best to deal with Zimbabwe was apparent after Western moves to impose United Nations Security Council sanctions were countermanded by an unprecedented double veto by the United States and Russia. On September 15, 2008 , after several rounds of negotiation, the major political protagonists agreed to form a unity government under the Global Political Agreement (GPA) framework which was concluded with South African facilitation. Zimbabwe's long-time ruler Robert Mugabe, and opposition leader Morgan Tsvangirai signed this power-sharing deal to resolve a political standoff stemming from controversial elections earlier in the year. This agreement, laid the foundations for a transitional inclusive government and outlined a time frame for the drafting and adoption of a new constitution. As part of the deal, which was not implemented until February 2009 under pressure from regional powers (SADC) and the international Community, Tsvangirai became prime minister of a new coalition government. Cabinet positions have since been divided among the parties. Many observers remain skeptical that the parties can work together effectively to implement political reforms deemed necessary by international donors. Since the formation of the inclusive government, the country has stabilized but significant challenges to the country's recovery still remain.

\section{Political System}

Since independence Zimbabwe has been parliamentary democracy, even though the country's Celections since 2000 has been disputed by sections of the international community. It is one - of a few select countries that have held elections consistently since independence. Another - milestone for Zimbabwe is that it has not experienced a military coup d'etat as has been the norm in most post-independent African countries. The Zimbabwe African National - Union Patriotic Front (ZANU PF) and its leader Robert Mugabe have been in power since independence in 1980. However, since 2000, ZANU PF has been facing a strong challenge for power from the Movement for Democratic Change (MDC) and its leader, Morgan Tsvangirai. Ther legislative branch is based on a bicameral parliamentary system consisting of a Senate ( 93 seats - 60 members elected by popular vote for a five-year term, 10 provincial governors nominated by the president and the prime minister, 16 traditional chiefs elected by the Council of Chiefs, 2 seats held by the president and deputy president of the Council of Chiefs, and 5 members appointed by the president) and a House of Assembly (210 seats - members elected by popular vote for five-year terms). Elections were last held on 28 March 2008. The country's constitution is based on the British authored Lancaster House Constitution of 21 December, 1979 which ushered in independence in 1980. However, the Lancaster House Constitution has since undergone several constitutional amendments. An attempt to write a home-grown constitution was unsuccessful after the referendum result rejected the adoption of this proposed constitution. Since February, 2009 when the inclusive government was sworn in, the country has been largely operating under the provisions 
of the Global Political Agreement. This power sharing agreement is now enshrined in Zimbabwe's Constitution, with an outlined time frame of eighteen months for drafting a new constitution and a nation-wide referendum on the document (Congressional Research Services 2010a: 6). Many commentators expect elections to be held several months after the referendum, but a timeline for elections is not provided in the GPA. Already a constituentbased outreach program is behind schedule by almost two years, and yet it affects the timing of the constitutional plebiscite and, in turn, elections.

\section{Foreign Relations}

International opinion and reaction on Zimbabwe has been divided on how to respond to Zimbabwe's economic and political crises. On one hand, Western nations and institutions have expressed opposition to Robert Mugabe's methods of rule, and have pursued policies intended to pressure the Zimbabwe government for reforms such as the imposition of sanctions, arms embargo, withdrawal of development assistance, and travel bans for ZANU PF ruling elites. On the other hand, Mugabe has enjoyed some sympathy in Africa, where he has been viewed as an elder statesman and a leader of the anti-colonial struggle, and among the Non-Aligned nations generally. This has changed to an extent in recent years, however, with some African leaders concluding that the Zimbabwe situation has been damaging to Africa's interests and that political and economic reforms are needed. Nevertheless, African countries supported Zimbabwe in its successful bid to chair the United Nations Commission on Sustainable Development in 2007, allegedly to show African solidarity against Western opposition. African Union (AU) member states were unable to come to a conclusion on how to address Zimbabwe's political situation at the 2008 AU Summit in Egypt, despite election observer reports from the AU, Southern African Development Community (SADC), and the Pan-African Parliament finding that the June 2008 runoff election was not free or fair. The international donor community has generally expressed support for the new inclusive government, formed under the GPA arrangement, but has predicated the removal of sanctions and resumption of development assistance on improvement in the following areas: "the immediate release of all political prisoners; the end of farm disruptions; the cessation of politically motivated violence; the establishment of a credible and transparent Reserve Bank team; an end to harassment and intimidation of the media; and a commitment of all stakeholders to holding credible elections in a timely manner" (Congressional Research Services, 2010a, p.35).

\section{United Kingdom}

In the context of the crisis in Zimbabwe, when we talk of the international factor that is most relevant to it, the visible role of the former colonial master, Britain, is very obvious. There are several aspects of Britain's connection to problems in Zimbabwe that need to be appreciated. First, Britain's relationship with Zimbabwe has been a key area in British foreign policy throughout the 20th century and since the dawn of the new century. Second, the above relationship is underpinned by the myriad personal, economic and cultural ties 
between the British and Zimbabwean peoples, particularly between the former and its White 'kith and kin'. During the early years of its independence, relations between the two countries was cordial, such that both countries shared similar views on many issues. However, in 1997 with the New Labour party at the helm of government, Britain shifted its policy of accommodating the Mugabe regime to one that became critical of the latter. The defining moment in Britain and Zimbabwe relations occurred at the 1997 Edinburgh, Commonwealth Heads of Government Meeting (CHOGM), where Mugabe had demanded $£ 150$ million pounds for land reform (McWilliam 2003: 96). And to the chagrin of the Mugabe regime, the British government not only refused to release the funds but also disowned its colonial responsibility as underscored in the November 1997 "I am not a colonialist" letter by the then British Secretary of State for International Development "Claire Short (GoZ, 2002, p.11-12). Furthermore, largely because of British opposition, which was aimed at slowing down the pace of land reform in Zimbabwe, pledges made by donors at a Land Donors Conference in 1998 were not honoured (Statement by the ZANU PF Deputy Secretary for External Relations \& Minister of Foreign Affairs 2004: 10; GoZ 2002: 13). In response, the ZANU PF government responded by inserting a provision (Clause 57) in the 1999 Draft Constitution which would allow the Zimbabwe government to acquire land and pay only compensation for the improvements to the land (farm equipment and physical structures) and not the land itself. The provision placed the obligation for land compensation on the former colonial power, Britain. However, when the draft constitution was rejected in a referendum in February, 2000 after heavy campaigning and lobbying by an alliance of the newly formed MDC, White farmers and civil society groups, a wave of nationwide land invasions erupted under the tutelage of liberation war veterans. Initially these land invasions were not part of any government programme but Clater the government went along with them due to their high political value. Nonetheless, the onset of land occupations set in motion Zimbabwe's rapid political and socio-economic

decline. The reaction of the British to Zimbabwe's accelerated land reform was sharp and hostile. Soon after the implementation of the Fast Track Land Reform Programme (FTLRP) - in 2000, Britain unleashed a major diplomatic offensive against Zimbabwe. Although the conflict between the two countries had initially started as a bilateral issue, Britain later decided to internationalise it by soliciting the support of the US and the EU (The Herald, 2010.). Unsurprisingly, the increasing confrontation between Britain and Zimbabwe over the land issue soon attracted the attention of the Commonwealth which was the first theatre of the British backlash against Zimbabwe (Statement by the ZANU PF Deputy Secretary for External Relations \& Minister of Foreign Affairs 2004: 16). In 2002, in conjunction with the United States and the European Union (EU), the British Parliament imposed targeted sanctions on leading members and affiliates of the ZANU-PF regime, as well an arms embargo and an asset freeze. The UK has since imposed travel bans on over 100 members of ZANU-PF and close associates of the party. Nevertheless, Britain continues to provide humanitarian aid in Zimbabwe. Equally, Mugabe was extremely hostile toward former British Prime Minister Tony Blair, and his successor, Gordon Brown, both persistent critics. The new British government under the Conservatives has not yet openly articulated its position on Zimbabwe, but indications so far show no signs of re-approachment. 


\section{US Policy}

In general, the United States (US) was critical of the ZANU-PF government for its alleged poor human rights record and lack of respect for the rule of law, but has expressed cautious support for the coalition government. The US hostility to Zimbabwe is epitomized by the Zimbabwe Democracy and Economic Recovery Act of 2001 (P.L. 107-99), which paved the way for the imposition of targeted and general sanctions. As a result, key elements of U.S. policy toward Zimbabwe have included targeted sanctions against high-ranking ZANU-PF members and their affiliates, economic sanctions against Zimbabwe such as instructing US officials in international financial institutions to oppose and vote against "any reduction or cancellation of indebtedness owed by the Government of Zimbabwe to the United States or any international institution" (ZIDERA 2001), support for South Africa to spearhead an African effort to restore democracy, and assistance intended to help the country's poor and strengthen civil society. Zimbabwe is also excluded from enjoying trade benefits under the US's Africa Growth and Opportunity Act (AGOA), allegedly because of its poor record of economic management and human rights abuses (Congressional Research Services 2010b: 36). Former Secretary of State Condoleezza Rice told the US Congress during her 2005 confirmation hearing that Zimbabwe was one of six "outposts of tyranny" worldwide (The others were Cuba, Burma, North Korea, Iran, and Belarus) and that the United States stood with the oppressed people there. Notably, the Mugabe administration has routinely blamed its economic crisis on sanctions imposed by the Western countries.

\section{European Union}

The relations between Zimbabwe and the EU chilled in the 1990s when the former began to have problems with Britain's New Labour government over the land issue. The European Union was among the first to take action against Mugabe's government. The EU imposed targeted sanctions on 19 members of Zimbabwe's elite and their spouses after pulling the EU election observer team out of Zimbabwe in February 2002 (The European Union, Council Regulation (EC) No 310/2002 on 18 February 2002). On July 22, 2002, the EU Council meeting in Brussels upgraded these sanctions by targeting 35 Zimbabwean leaders, and have since been renewed yearly, with new names added on an annual basis. Current EU sanctions include a travel ban on over 160 members and beneficiaries of the ZANUPF, an arms embargo, and an asset freeze. Mugabe defied the travel ban in 2005 to attend the funeral of Pope John Paul II. However, the EU continues to provide humanitarian and limited development assistance.

\section{Commonwealth}

The Commonwealth of Nations sent a team of observers to the March 2002 presidential election in Zimbabwe, and the group In its preliminary report on 9-10 March, 2002, concluded that "the conditions in Zimbabwe did not adequately allow for a free expression of will by the electors". (Commonwealth Observer Group's Preliminary Report on Zimbabwean 
Presidential Elections, March 14, 2002). Almost immediately after the Presidential elections in Zimbabwe, the Commonwealth moved to suspend the country. The decision was eventually made by the leaders of South Africa, Australia and Nigeria after the studying the Commonwealth Observer Report which had made a scathing attack on the conduct of elections. These three countries constituted a special committee appointed to monitor and respond to the electoral process in Zimbabwe. Zimbabwe would be suspended from the Commonwealth for one year. The suspension was the first public rebuke against the Mugabe regime by a body that included influential African countries. At the Abuja CHOGM in Nigeria, in December 2003, Zimbabwe's suspension was reaffirmed despite South Africa's protestations. Mugabe responded by withdrawing Zimbabwe from the Commonwealth and ruling out any further discussions or a possible return. Some speculated, as a result, that the Commonwealth's action had backfired by placing Zimbabwe fully outside the bounds of its influence. Others argued that indefinite suspension by a body including many African member states had important symbolic value in Africa and worldwide.

\section{China, Russia, India and Iran}

-

While many Western governments moved to isolate the ZANU-PF government in the last decade, China, Russia, India and Iran strengthened ties and deepened their involvement in Zimbabwe's economy. In 2003, Zimbabwe adopted the Look East Policy with the objective of dealing with Zimbabwe's severe economic difficulties and estrangement from Western technology, capital, trade and political support. The Zimbabwean Look East Policy which has seen Zimbabwe enjoying cordial relations with South Asian countries and Far Eastern countries like China, Iran, Malaysia, Singapore, Indonesia, India and Pakistan gave birth to Pa number of economic and technical agreements with the numerous countries. However, in - recent years it appears that the focus is now on China, which incidentally was ZANU PF's - mentor and main backer during the liberation struggle in the 1960s and 70s. China is reported to be Zimbabwe's second-largest trading partner and its largest investor (Financial Times, - 2007). Other media reports indicate that China is expected to invest a total of US\$10 billion in the Zimbabwean economy (Financial Gazette Online, 2011). The resulting relationship between China and Zimbabwe is very close and mutually advantageous. China views Zimbabwe as an China is reported to be Zimbabwe's second-largest trading partner and its largest investor ( Financial Times, 2007). important strategic partner in southern Africa. On the other hand, Zimbabwe needs investment due to Western disinvestment. Hence, Chinese companies are involved in major infrastructural projects in Zimbabwe. In addition to this, China has also been providing aid to schools, hospitals and other sectors which would help to stabilise the country. Many observers see Zimbabwe's rich reserves in platinum, and diamonds as a major draw for Beijing, and Chinese firms are playing roles in the cell phone industry, as well as in television, radio, and power generation. Furthermore, China holds controlling interest in the country's only electricity generator. Arms deals between China and Zimbabwe have attracted considerable international attention in recent years, as most Western governments continue to enforce an arms embargo against the country. Zimbabwe's reported \$240 million purchase of 12 Chinese fighter jets drew questions from analysts as to 
why a country that faces no immediate external threat from its neighbors would need such an air force. (Congressional Research Serviuces 2010b: 41).

The Russians have also invested in Zimbabwe's key mining sector. India is also raising its stake in Zimbabwe with Indian iron and steel giant Essar buying Zimbabwe's derelict Zimbabwe Iron and Steel Company, ZISCO. This acquisition is the largest single foreign investment into Zimbabwe since independence 31 years ago. In the face of Western condemnation and isolation, Zimbabwe also found an ally in Iran. During a 2006 visit to Tehran, President Mugabe reportedly secured commitments from Iran for direct aid and Iranian assistance to its energy, agriculture, and mining industries. Reports indicate that Iran or one of the Gulf countries may also be provide technical assistance to Zimbabwe - to revive the country's only oil refinery, built 40 years ago to process Iranian crude. Most of Zimbabwe's fuel comes by road from South Africa; the country has insufficient foreign currency to import fuel in bulk through a pipeline from the nearest port, Beira, Mozambique, to Zimbabwe.

Perhaps the defining moment of Zimbabwe's strengthening relations with non-Western - powers was demonstrated on 11 July, 2008 when a Western-sponsored UN Security Council was defeated through a double veto from China and Russia. The draft resolution concerning the situation in Zimbabwe (Document S/2008/447) was co-sponsored by Australia, Belgium, Canada, Croatia, France, Italy, Liberia, New Zealand, Netherlands, Sierra Leone, United Kingdom and the United States (United Nations Security Council SC/9396 on the Security Council 5933rd Meeting, 11 July, 2008). The draft resolution would have determined, under Chapter VII of the United Nations Charter, that the situation in Zimbabwe posed a threat to international peace and security in the region. The result of the Security Council's vote was 9 in favour (Belgium, Burkina Faso, Costa Rica, Croatia, France, Italy, Panama, United Kingdom, United States), to 5 against (China, Libya, Russian Federation, South Africa, Viet Nam), with Indonesia abstaining. However, the fact of the matter is that if the draft resolution had been passed under Chapter VII it would have tacitly approved military intervention in Zimbabwe which was being coveted by Britain and other Western powers.

\section{SADC and the African Union}

The African Union (AU) and its predecessor, the Organization of African Unity (OAU), have been supportive of Mugabe in the past. In 2002, an OAU observer team labeled Mugabe's contested election victory legitimate, free, and fair. In 2004, when the AU allowed a report critical of the Mugabe government to be circulated at its annual summit, some believed the regional body might be indicating a change in its approach. The 114 page report, prepared by a delegation from the African Commission for Human and People's Rights (ACHPR) that visited Zimbabwe in 2002, reportedly castigated the Zimbabwe government for human rights abuses, media censorship, and compromising the judiciary. The AU tabled the report at the summit, however, and declared it would keep its contents secret until Zimbabwe has had a chance to respond in detail. According to some media reports, the Zimbabwean government used procedural regulations and technicalities to prevent its release. In much the same way, many of the 14 members of the Southern African Development Community 
(SADC) are supportive Mugabe and his ruling ZANU PF. Many of these countries are linked to Zimbabwe by a common historical experience, as well as cultural and economic ties. As such, the organization has been seen as disinclined to condemn the actions of President Mugabe's government. Although Mugabe's neighboring leaders have not singled him out for criticism, with the exception of Botswana, and Zambia (especially when it was under the rule the late Levy Mwanawasa), they have been increasingly concerned with the impact of Zimbabwe's crisis on their own countries. Southern African leaders blamed Zimbabwe and Swaziland for undermining economic growth in the region at a SADC Summit in Lesotho in 2006. Botswana has spoken out vigorously on regional problems attributed to Mugabe's policies, including the burden placed on the country by Zimbabwe's refugees. Furthermore, Botswana refused to recognize Mugabe as president after the June 2008 runoff. Pressure from SADC does appear to have compelled Zimbabwe main political parties to join together in the new coalition government, under the GPA framework, but it remains unclear to what extent they might be willing to enforce the deal if the parties cannot work together. At a SADC summit of the organ Troika on Politics, Defence and Security Cooperation, in Livingstone, Zambia, on March, 2011, SADC urged "Zimbabwe

(1) immediately end violence, intimidation, hate speech, harassment and any other form of action that contradicts the letter and spirit of the Global Political Agenda (GPA)". In its Communique, the SADC summit further noted "with grave concern the polarization of the political environment in Zimbabwe as characterized by the resurgence of violence, arrests and intimidation".



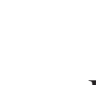

\section{Administrative Set-up}

Being a relatively small country, Zimbabwe was always a unitary state, except for a brief 10 year period when it was part of the Federation of Rhodesia and Nyasaland between 1953 and 1963. Presently, the country has ten administrative divisions comprising eight provinces and two cities with provincial status. These divisions are Harare, Bulawayo, Manicaland, Mashonaland Central, Mashonaland East, Mashonaland West, Masvingo, Matabeleland North, Matabeleland South, and Midlands. In recent years, there has been - "calls in favour of federalism from certain political activists and civil society groups based in the Matabeleland regions, which are dominated by the minoritry Ndebele ethnic group. The country's legal system is a mixed legal system of English common law, Roman-Dutch civil Jaw, and customary law. The judicial branch comprises a Supreme Court which doubles up as the Constitutional Court; a High Court ; and lower courts. The official retiring age for civil servants is 60 years. However, the Public Service Commission may permit a member whose pensionable age is 60 to continue to serve beyond the age of 60 for periods not exceeding one year at a time (Statutory Instrument 1 of 2000, Public Services Regulations, 2000).

\section{Economy}

Zimbabwe's economy is slowing recovering under the coalition government despite signs of continuing political uncertainty. Following a decade of sharp economic decline, the country's economy recorded real growth of $5.9 \%$ in 2010. But the government of Zimbabwe 
still faces a number of difficult economic problems, including a large external debt burden and insufficient formal employment. Economic sanctions, withdrawal of development assistance by Western countries and negative media reportage by mainly Western media has had a negative impact on Zimbabwe's economy since the late 1990s. Zimbabwe's 19982002 adventure in the war in the Democratic Republic of the Congo drained hundreds of millions of dollars from the economy, and thus also contributing to the freefall of the economy. Similarly, the government's 'fast track' land reform programme implemented to redress historical imbalances, was characterized by chaos and violence, and badly affected the commercial farming sector, which was the traditional source of exports and foreign exchange and the provider of 400,000 jobs. In the short-run, this transformed Zimbabwe , from being Africa's 'food basket' into a net importer of food products. The EU and the US provide food aid on humanitarian grounds, though on a smaller scale than before. In recent years, there are indications that the agricultural sector, now dominated by smallscale black commercial farmers, is on the mend. The country's central bank, the Reserve Bank of Zimbabwe (RBZ), routinely printed money to fund the budget deficit under its quasi-fiscal policy, thereby causing hyperinflation which rose above $200,000,000$ at its peak in 2008. The power-sharing government formed in February 2009 has led to some economic improvements, including the cessation of hyperinflation by eliminating the use of the Zimbabwe dollar and removing price controls. The economy is registering its first growth in a decade, but will be reliant on further political improvement for greater growth. Although the economy has since stabilized, unemployment remains estimated at more than 90\% (CIA World Fact Book, 2011).

\section{Zimbabwe at Glance}

Capital City: Harare

Population: 12.4 million

Approximate size: Slightly larger than Montana (US)

Population growth rate: $0.568 \%$

Life expectancy at birth: 39.7 years

Ethnic groups: African 98\% (Shona 82\%, Ndebele 14\%, other 2\%), Mixed and Asian

$1 \%$, White less than $1 \%$

Religions: syncretic (part Christian, part indigenous beliefs) $50 \%$, Christian 25\%, indigenous beliefs $24 \%$, Muslim and other $1 \%$

Languages: English (official), Shona, Sindebele and a number of tribal dialects.

Literacy: Total Population: 90.7\%; Male: 94.2\%; Female: $87.2 \%$

GDP real growth rate: $-6.1 \%$

GDP Per Capita: $\$ 158$

HIV Infection Rate: $18.1 \%$ (adults, aged 15-49)

Unemployment: $80 \%$

Administrative divisions: 8 provinces and 2 cities with provincial status

Independence: 18 April 1980 (from the UK) 
National holiday: Independence Day, 18 April (1980)

Major Political Parties: Movement for Democratic Change or MDC [Morgan TSVANGIRAI]; Movement for Democratic Change - Mutambara or MDC-M [Arthur MUTAMBARA] (splinter faction of the MDC); Zimbabwe African National UnionPatriotic Front or ZANU-PF [Robert Gabriel MUGABE]; Zimbabwe African Peoples Union or ZAPU [Dumiso Dabengwa]

Sources. CIA World Factbook; Economist Intelligence Unit; UNAIDS.

\section{References}

African All Party Parliamentary Group (AAPPG). (2009). Land in Zimbabwe: Past mistakes, future prospects, United Kingdom:

Beijing quietly cools relations with Mugabe. (2007, June 5). Financial Times.

Central Statistical Office (CSO). (1985). Statistical yearbook. Harare: Government publishers.

Chaumba, J, Scoones, I \& Wolmer, W. (2003). From Jambanja to planning: The reassertion of technocracy in Land Reform in South-Eastern Zimbabwe? The Journal of Modern African Studies, 41(4), 533-554.

CIA World Fact Book. (2011). Retrieved from https:/www.cia.gov/library/publications/ the-world-factbook/geos/zi.html

- Commonwealth Observer Group's Preliminary Report on Zimbabwean Presidential Elections," .(2002, March 14). Retrieved from http://www.afrol.com

Communique Summit of the Organ Troika Politics, Defence, and Security Cooperation. (2011). Livingstone, Zambia.

Congressional Research Services - Prepared for Members and Committees of Congress of the United States. (2010a). Zimbabwe: The transitional government and Implications for US Policy, by Lauren Ploch - Analyst in African Affairs, July 8, 2010.

Congressional Research Services - Prepared for Members and Committees of Congress of the United States. (2010b). Zimbabwe: Background, by Lauren Ploch - Analyst in African Affairs, July 8, 2010.

Facchini, M. (2007), The 'Evil Genius': Sir Hugh Beadle and the Rhodesian Crisis, 19651972, Journal of Southern African Studies. 33, (3) 673-689. 
Beijing quietly cools relations with Mugabe. (2007, June 5). Financial Times.

Government of Zimbabwe (GoZ). (2002). The commonwealth and the Zimbabwe Presidential election. Harare: Government Printers.

Statutory Instrument 1 of 2000, Public Services Regulations.(2000).

United Nations. The Report of the Fact-Finding Mission to Zimbabwe to assess the scope and impact of operation Murambatsvina by the United Nations special envoy on human settlements issues in Zimbabwe, Anna Tibaijuka. (Tibaijuka Report).

- United Nations Security Council SC/9396 Security Council 5933rd Meeting (PM), 11 July 2008 ,

Rice targets 6 ‘Outposts of Tyranny’. (2005, January 19). Washington Times. 